\title{
SYNTHESISING THEORY AND PRACTICE IN TEACHER EDUCATION THROUGH LEARNING STUDY
}

\author{
Keith Wood \\ Sultan Hassanal Bolkiah Institute of Education \\ Universiti Brunei Darussalam
}

\begin{abstract}
:
This paper outlines and exemplifies the features of Learning Study, a form of teacher action research which has the potential to create the conditions necessary for building pedagogical knowledge. Learning Study is a coalescence of lesson study, design based research and the Variation Theory of learning. It places emphasis on the determination of the object of learning and its critical aspects as a precursor to the design of learning situations. The Learning Study process and outcomes are described here with reference to a study of high school students learning to interpret contour maps. Being explicit about learning theory is seen to afford the opportunity to transform teacher education and professional development through clinical practice.
\end{abstract}

Keywords: Learning study; variation theory; pedagogical knowledge.

Corresponding author: Keith Wood

E-mail: keith.wood@ubd.edu.bn

Submitted for publication 26/06/2012

Accepted for publication 02/11/2012

Educational Research eJournal ISSN 2254-0385

(C) Faculty of Education. University of Alicante

DOI:10.5838/erej.2013.21.01 


\section{Introduction}

This paper arises from discussions at the EU - Asia Seminar on Teacher Education Policy (2012) sponsored by the European Network of Educational Research on Citizenship Education (ENERCE). It is a response to the question of how theory and practice can be effectively synthesised in an approach to the development of teachers. In answer to the question, this paper outlines the features of Learning Study, an admixture of learning theory and Japanese lesson study (Yoshida, 1999) developed through a sustained international dialogue of more than a decade between teacher educators in Europe and Asia-Pacific which has the potential as a form of teacher action research to create the conditions necessary for the 'production of pedagogical knowledge in propositional and actionable form' (Elliott, 2009).

\section{Phenomenography, variation theory and the design of learning situations}

Learning Study is a coalescence of lesson study (Lewis, Perry and Friedkin, 2009) with design based research (Kelly, Lesh and Baek, 2008) and a particular theory of learning referred to as Variation Theory. It places emphasis on the determination of the object of learning and its critical aspects as a precursor to the design of learning situations (see Figure 1). The theory used in learning study was developed from the phenomenographic research approach to learning (Marton and Booth, 1997) to explain the conditions necessary for the design of effective learning situations. Hitherto the outcome of phenomenographic studies had been mappings of qualitatively different, often hierarchically related, conceptions of phenomena derived mainly from iterative analysis of deep interview data. The departure for phenomenography was to ask what it takes to change the conception of a phenomenon held by an individual for a better one, one which has more explanatory power. For example, a phenomenographic study of price (Dahlgren and Marton, 1978) identified two conceptions of price: 1) price experienced as a property of a commodity comparable with its colour, size and weight, and 2) price experienced as an entity determined by a dynamic market system. For anyone teaching price, the implication is clear. It is better to understand price determination as a function of the conditions operating in the market for the commodity of interest. This becomes the object of learning in the Learning Study. Learners who experience price as a property of a commodity are not aware of the role of the market in determining price. A learning situation should be designed to bring this critical aspect of price into focus for them.

According to variation theory (Runesson \& Marton, 2002; Marton \& Tsui, 2004), individual learning results from the discernment of critical aspects of objects and situations and from focusing on them simultaneously. A critical aspect is an aspect of the object of learning which is necessary for a particular meaning to appear in the learner's awareness. The presence or absence of any critical aspect distinguishes between one meaning of the object of learning and another. An aspect can be discerned only if the learner experiences variation along a dimension corresponding to that aspect against a background of invariance in other aspects. The variation theory predicts that a designed experience of an appropriate pattern of variation and invariance is a necessary condition for learning because an aspect can be discerned only if the learner experiences variation along a dimension corresponding to that aspect against a background of invariance in other aspects. For example, 
with reference to the example of teaching price, a learning situation designed to bring about change in learners' conception of price might task learners to reflect on why a particular brand of cola has different prices in different locations - a hotel, a supermarket chain, an independent retailer, a low-cost airline flight and so on (Davies \& Brant, 2006). In this learning activity, the product is invariant but the market conditions prevailing in the different locations vary. For a small, independent retail outlet, pricing is competitive but airline flight pricing is less so. The price is likely to be higher in the air. The learners have the opportunity to learn from the difference to see that commodities are not produced with prices but that market structure determines the price at which they will be bought and sold. In this case, the commodity is invariant but the market structure varies. Learning something in a particular way requires that the learner experiences simultaneously patterns of variation corresponding to the critical aspects of the object of learning.

The steps in a Learning Study are similar to the action research cycle of lesson study:
-A group of teachers, supported by a consultant, decide on an object of learning -A topic or principle or approach to problem solving that is included in the curriculum.

-Drawing on information about the learners' different ways of experiencing the object obtained by a pre-test and by pooling the teachers' experience of teaching the object, the Learning Study group designs the new lesson(s).

-Variation is used as a tool for designing the new lesson(s).

-One of the teachers teaches the new design. Evidence is collected through observation and video-recording of the lesson, and learners are post-tested and may be interviewed.

-The Learning Study group considers the evidence and analyses the test results. If they find the learning outcomes unsatisfactory, they review the design.

-If necessary, the next teacher teaches the revised design in her class and evidence is collected.

-The Learning study continues in a cyclical process of improvement until the group is satisfied with the design.

Figure .1 Learning Study.

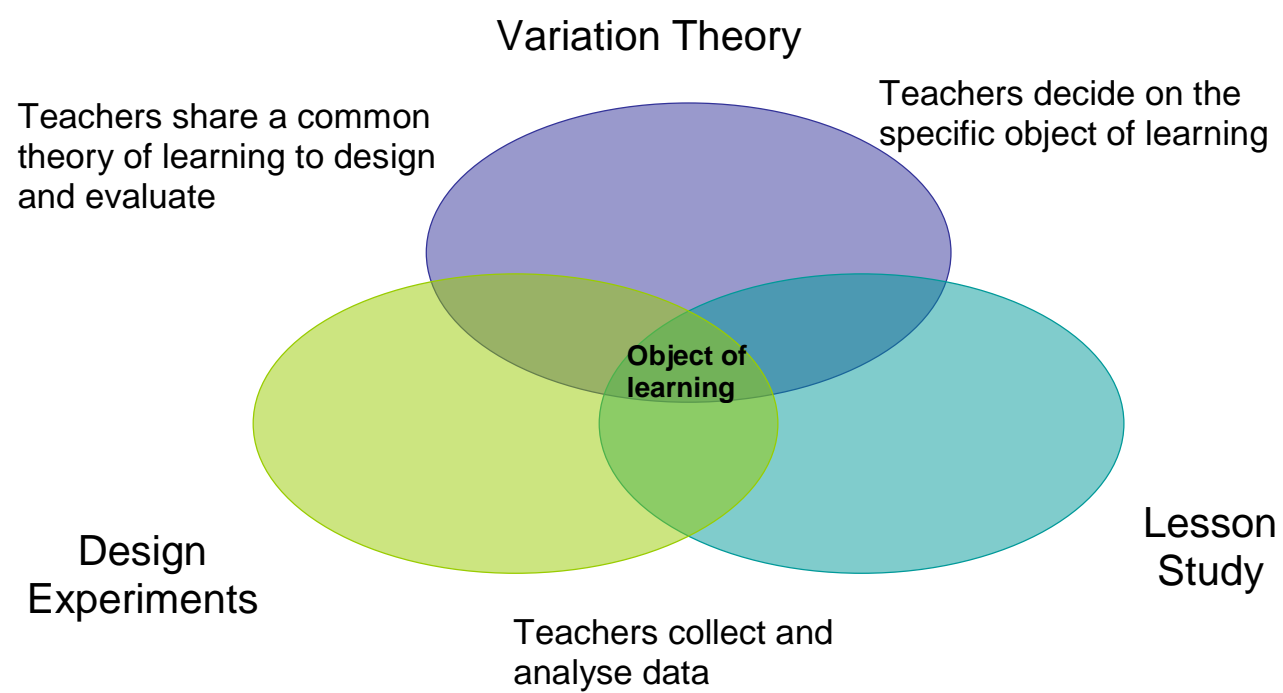




\section{An example of Learning Study conducted by social science teachers}

\subsection{The object of Learning}

The Identification of an object of learning, its critical aspects and appropriate dimensions of variation, is not a simple process. The research results are not available - as they are for the price example - to cover all the topics of the curriculum to be taught. In the example reported here, the object and its critical aspects and appropriate dimensions of variation had to be determined by teachers. To support them the teachers could draw on variation in three ways (Lo, Pong and Pakey, 2005):

-V1. Variation in terms of students' ways of experiencing the object of learning.

-V2. Variation in teachers' ways of preparing to teach the object of learning.

-V3. Variation as a pedagogical tool.

With the knowledge gained from the first and second forms of variation, the teachers in the learning study attempted to identify the critical features of the object of learning. They then decided on what aspects to focus, what aspects to vary simultaneously, and what aspects are to remain invariant or constant, and to consciously design a pattern of variation to bring about the desired learning outcomes (Holmqvist, Gustavsson and Wernberg, 2008).

In this example of Learning Study, four teachers, each with nine years of experience of teaching high school geography, and their tutor undertook the study as part of a module of a Masters in Education (MEd) degree (Zakaria, Abd Rahman, Md Salleh and Husin, 2010). Two classes of year nine students (females, 13 - 14 year olds) were chosen for the study. Class 9A (20 students) was described by the teachers as a higher ability class in comparison with class $9 \mathrm{~J}$ (15 students). The teachers agreed to focus on the object of learning to interpret two-dimensional contour maps as representations of three-dimensional land relief. The group selected the topic because they had found from experience that their geography students have difficulty in visualizing what is drawn on a map; they have difficulty in moving from two-dimensions on maps to the three-dimensional features represented by the contours. It was reported that some students read every set of contours as a positive elevation. This problem appeared to be one of perception. Just as it impossible to know the threedimensional shape of the cube in Figure 2 without depth clues, so it is impossible to interpret a contour map without paying close attention to the numbers on the contours.

Figure 2. Perception of depth
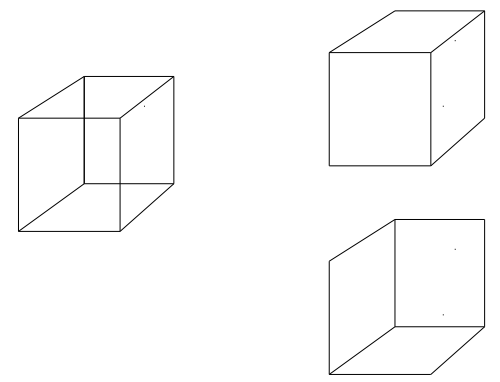

\subsection{The design tool}

The lesson was designed to provide a pattern of variation to foreground contour numbers as a critical aspect of the interpretation of maps. It aimed to help the learners see how changing land relief may or may not be related to a change in the contour numbers, how an increase or decrease in contour numbers will indicate a change in the relief of the land, and that reversing the contour numbers would change the feature of the land for highland to depression. The pattern of dimensions of variation (V) and invariance (I) are summarised in Table 1. 


\begin{tabular}{|c|c|c|c|}
\hline $\begin{array}{c}\text { Contour map shape } \\
\text { (2D) }\end{array}$ & Contour numbers & Elevation & $\begin{array}{c}\text { Visualisation } \\
\text { (3D) }\end{array}$ \\
\hline $\mathrm{V}$ & $\mathrm{I}$ & $\mathrm{I}$ & $\mathrm{V}$ \\
\hline $\mathrm{I}$ & $\mathrm{V}$ & $\mathrm{I}$ & $\mathrm{V}$ \\
\hline $\mathrm{I}$ & $\mathrm{I}$ & $\mathrm{V}$ & $\mathrm{V}$ \\
\hline
\end{tabular}

Table 1. Design tool.

\subsection{Pre- and post-test items}

Both classes were given a pre- and posttest designed by the teachers to establish baseline data on performance before the lessons and to record any improvement. The test is shown in Figure 3 and Table 2.

\subsection{Lesson design}

The lesson design involved the following activities:

-A two dimensional contour map is projected on to the white board

-A Styrofoam sheet is placed against the board and the contour map is traced on to it

-Sections are cut from the sheet

-Using the Styrofoam sections, students build three dimensional models

-Based on the design tool, students investigate a structured series of variations (see Figure 4)

The design tool could be used to create alternative lesson designs. For example, with appropriate resources, it would be possible to explore the structured series of variations by reversing the operations, moving from a three-dimensional model to a two dimensional representation on a map. In Learning Study, the focus of the teachers' attention is not the teaching method per se but the identification of the object of learning and the development of the design, which can often be realised in a number of ways.

Figure 4 shows students working with the models that they have created elevations and depressions - to explore the dimensions of variation.

\section{Results}

The teachers were impressed by the results of the post-test (Table 3) which showed an increase in the mean mark for class 9A from 8.8 to 16.3 and for class $9 \mathrm{~J}$ from 5.4 to 12.4 . There was support from the students for this approach to the object of learning exemplified by these observations made during interviews carried out by the teachers:

I prefer to be taught by using the model because I can understand more easily and I can see the real feature. (9A student)

It is more fun to see models rather than just drawings on the whiteboard. (9J student)

The teachers checked out items for which there was little improvement and in cases where individuals negated a previously correct answer. Students explained that these items were too easy; that items three and four were similar to items one and two, and produced some careless responses. They checked also for items showing a significant improvement using a twotailed test (Tables 4 and 5). 
Figure 3. Map used in the pre-and post-tests

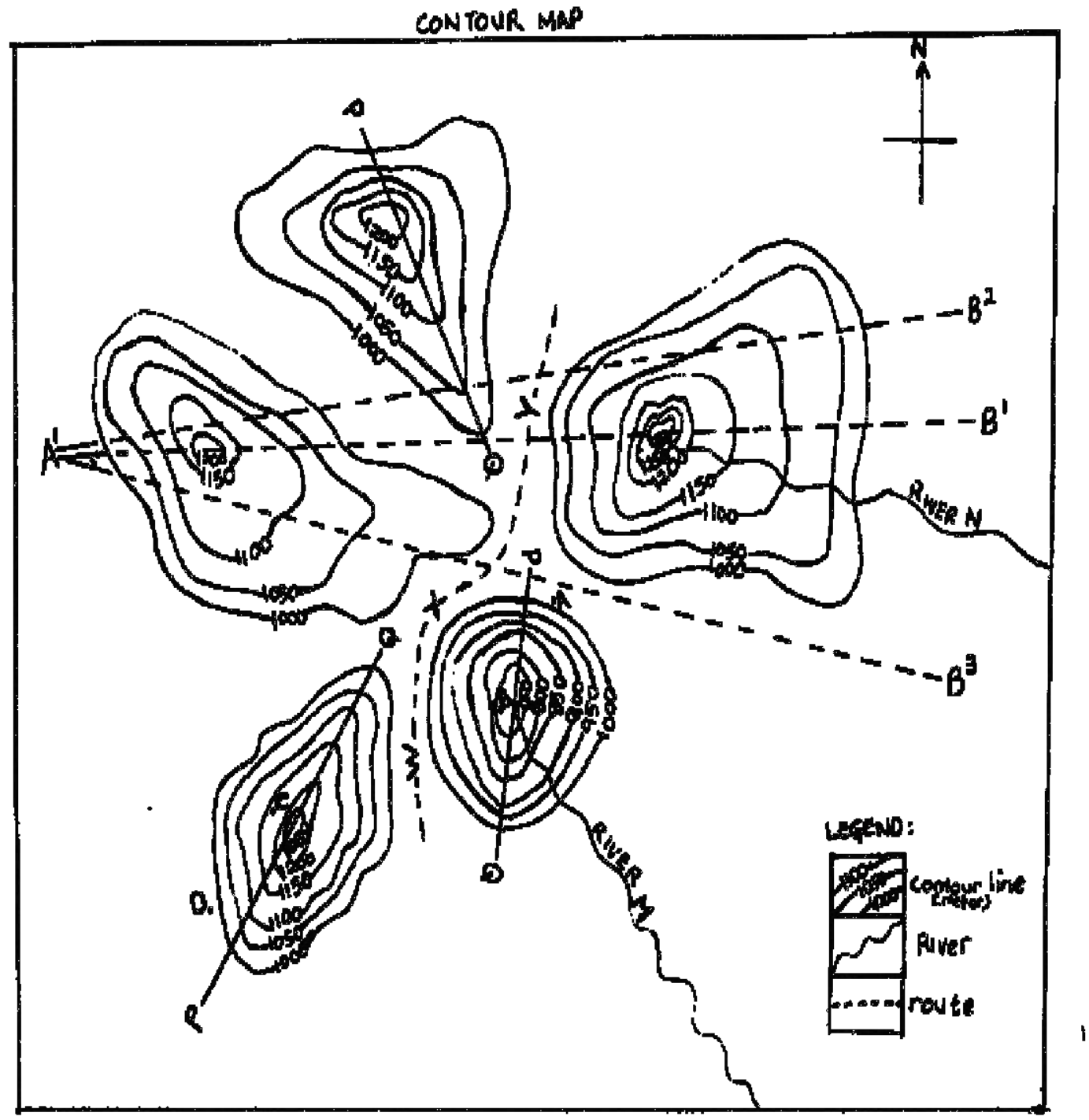




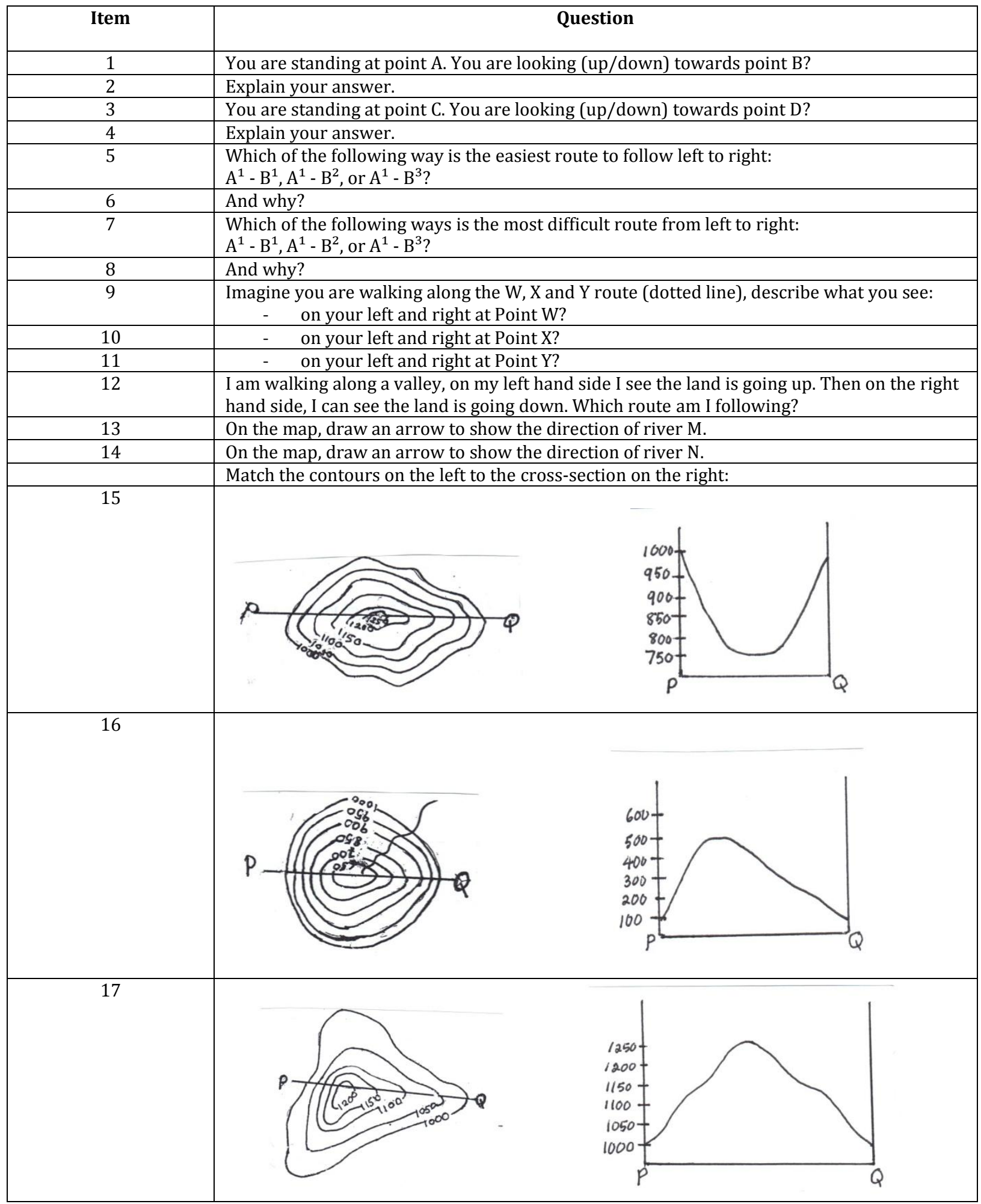

Table2. Items used in the pre-and post-tests. 
Figure 4. Students working with their models
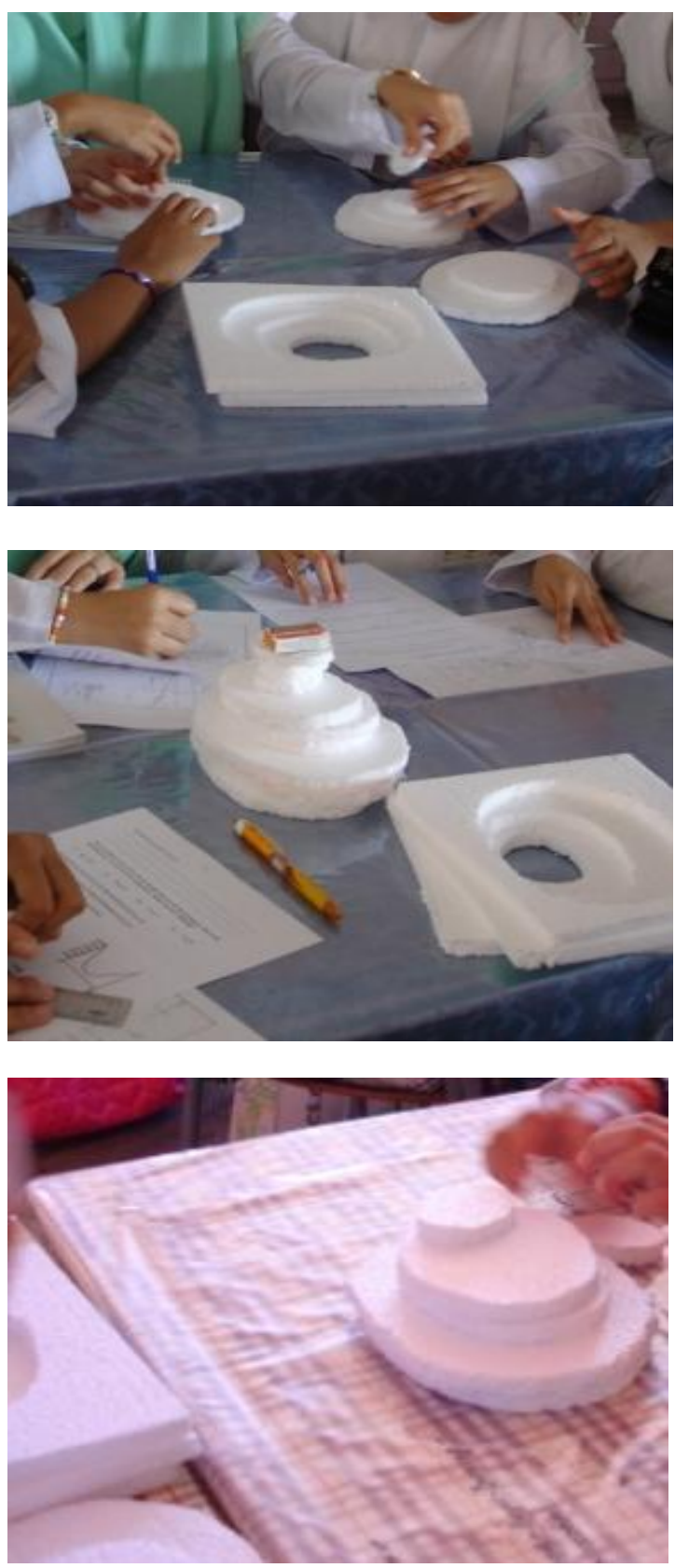

\section{Discussion}

In the example included here, the teachers completed one cycle of Learning Study. Had the design been less effective, a second cycle would have afforded the teachers the opportunity to reflect on the evidence, to redesign and to teach the object again to another class. This is not to suggest that there is room for complacency in the light of the outcomes of this example since there remains the problem of students who still do not see what was intended. While the experience of variation may be a necessary condition for learning it may not be sufficient for every learner (Marton and Pang, 2006). There is also scope for analysing in detail the way in which the two lessons for $9 \mathrm{~A}$ and $9 \mathrm{~J}$, taught by different members of the group but observed by all, were enacted. Encouraging teachers to reflect on the variation in the ways in which ostensibly the same object is taught can be an effective way for a group to identify the object itself (Marton \& Tsui, 2004).

The teachers engaged in this Learning Study found much to commend this approach to professional development:

... We have learnt more content (on the topic contour lines) and developed better insight into students' thinking from each other in the context of what occurs in the classroom and from interviews as well as analyzing their pre- and post-test.

... Learning Study can serve as a catalyst for enabling teachers and administrators to arrive at a shared understanding of specific actions and expectations to help minimise students' confusion level. We believe that Learning Study can help us and other teachers to reach a common understanding of student thinking, determine a common set of expectations for student work and achievement, and collaboratively develop a powerful array of strategies to move students to higher levels of understanding and accomplishment.

... Learning Study can become the basis of school-based professional development, which treats teachers as professionals and builds their capacity for lifelong learning. It can help integrate the variety of professional development activities, courses, conferences, and workshops that teachers attend individually or in groups. 
Learning study can serve as the means by which teachers can share the knowledge they gained from their various professional development experiences and channel them into the collaborative research lessons they developed and then teach while assessing student learning and understanding.

This work involves meeting outside the classroom, as well as in the classroom itself. ... it is important that all members of the group understand that they are there to observe the lesson and the student responses-not to critique their actions. The process should be a shared one in which the whole team takes ownership of the lesson and is supportive of the team member who volunteers to teach it. We came to realize that getting involved in a learning study process is kind of tremendous feelings of satisfaction and accomplishment, and those who volunteer to teach the lesson tend to derive the greatest benefits. (Zakaria, Abd Rahman, Md Salleh and Husin, 2010)

Elliott and $\mathrm{Yu}$ (2008) who authored an evaluation of the Hong Kong Government sponsored three-year project entitled Variation for the Improvement of Teaching and Learning ("VITAL") 20037 reported a similar response to these teachers. In an empirical study of what it takes to change pre-service teachers' conceptions of the object of learning to teach, Wood (2000) reported some success from encouraging teachers to focus on V1-3. However, Davies and Dunnill (2008) found that the need to access the learners' experience to determine the pattern of variation could be too challenging for some student teachers. Andrew (2011) has reported that Learning Study as a professional development activity makes heavy demands on teachers' subject knowledge. In the context of his study in Brunei Darussalam, he reported that the participation of some teachers can be constrained by what they see as a tradeoff between meaningful learning from redesigned lessons arising from engagement with Learning Study and the need to cover the syllabus for examinations. But he noted that participation can have a transformative effect on those who engage fully with learning study.

\section{Conclusion}

The use of an explicit theory of learning distinguishes Learning Study from other types of lesson study where the contribution of theory can remain tacit (Lo and Marton, 2012). It provides the participants with a common vocabulary for design and evaluation. Alternatives to variation theory could be used to provide the design tools for learning study. For example, design based research in Europe attempts to derive such tools from 'grand' theories such as constructivism (Ruthven, Laborde, Leach and Tiberghien, 2009) to create effective lessons. It is a question of what works best. Learning Study supports the development of clinical practice whereby the object of learning is explicitly emphasised, combining content, pedagogy, and evidence of the lived experiences of individual learners, and where the outcomes are evaluated by the teachers themselves on the basis of evidence and can be reported for the information of others so that they can see what works and why. Being explicit about theory has the potential to transform teacher education and professional development. 


\begin{tabular}{|c|c|c|c|c|c|c|c|c|c|}
\hline \multirow[t]{2}{*}{ Student ${ }^{1}$} & \multicolumn{4}{|c|}{$\begin{array}{c}\text { 9A } \\
\text { Total marks for pre-and post-tests }\end{array}$} & \multirow[t]{2}{*}{ Student $^{2}$} & \multicolumn{4}{|c|}{$\begin{array}{l}\text { 9J } \\
\text { Total marks for pre-and post-tests }\end{array}$} \\
\hline & $/ 17$ & $\%$ & $/ 17$ & $\%$ & & $/ 17$ & $\%$ & $/ 17$ & $\%$ \\
\hline 2 & 4 & 24 & 17 & 100 & 1 & 4 & 24 & 12 & 71 \\
\hline 3 & 9 & 53 & 15 & 88 & 2 & 3 & 18 & 15 & 88 \\
\hline 4 & 6 & 35 & 17 & 100 & 3 & 5 & 29 & 15 & 88 \\
\hline 5 & 7 & 41 & 14 & 82 & 4 & 3 & 18 & 14 & 82 \\
\hline 6 & 8 & 47 & 15 & 88 & 5 & 4 & 24 & 9 & 53 \\
\hline 7 & 9 & 53 & 17 & 100 & 6 & 6 & 35 & 8 & 47 \\
\hline 8 & 11 & 65 & 17 & 100 & 8 & 8 & 47 & 15 & 88 \\
\hline 9 & 14 & 82 & 17 & 100 & 9 & 8 & 47 & 14 & 82 \\
\hline 10 & 12 & 71 & 16 & 94 & 10 & 6 & 35 & 17 & 100 \\
\hline 11 & 7 & 41 & 17 & 100 & 11 & 8 & 47 & 14 & 82 \\
\hline 12 & 10 & 59 & 16 & 94 & 12 & 5 & 29 & 12 & 71 \\
\hline 13 & 13 & 76 & 17 & 100 & 13 & 7 & 41 & 11 & 65 \\
\hline 14 & 13 & 76 & 17 & 100 & 14 & 4 & 23 & 9 & 53 \\
\hline 15 & 3 & 18 & 17 & 100 & 15 & 5 & 29 & 9 & 53 \\
\hline 16 & 5 & 29 & 16 & 94 & 16 & 5 & 29 & 12 & 71 \\
\hline 17 & 8 & 47 & 16 & 94 & Total & 81 & & 186 & \\
\hline 18 & 10 & 59 & 16 & 94 & & & & & \\
\hline 19 & 8 & 47 & 17 & 100 & & & & & \\
\hline 21 & 11 & 65 & 15 & 88 & & & & & \\
\hline 22 & 7 & 41 & 17 & 100 & & & & & \\
\hline Total & 175 & & 326 & & & & & & \\
\hline \multicolumn{5}{|c|}{$\begin{array}{c}{ }^{1} \text { Students } 1 \text { and } 20 \text { were absent for one of the } \\
\text { tests }\end{array}$} & \multicolumn{5}{|c|}{${ }^{2}$ Student 7 was absent for one of the tests } \\
\hline
\end{tabular}

Table 3. Test scores.

\begin{tabular}{|c|c|c|c|c|c|}
\hline Item & Item & Total mark & Mean & Std. Deviation & Sig. (2-tailed) \\
\hline Pre-test & \multirow[t]{2}{*}{1} & 7 & 0.35 & 0.489 & \multirow[t]{2}{*}{0.000} \\
\hline Post-test & & 20 & 1.00 & 0.000 & \\
\hline Pre-test & \multirow[t]{2}{*}{2} & 3 & 0.15 & 0.366 & \multirow[t]{2}{*}{0.000} \\
\hline Post-test & & 19 & 0.95 & 0.224 & \\
\hline Pre-test & \multirow[t]{2}{*}{5} & 14 & 0.70 & 0.470 & \multirow[t]{2}{*}{0.010} \\
\hline Post-test & & 20 & 1.00 & 0.000 & \\
\hline Pre-test & \multirow[t]{2}{*}{6} & 11 & 0.55 & 0.510 & \multirow[t]{2}{*}{0.001} \\
\hline Post-test & & 20 & 1.00 & 0.000 & \\
\hline Pre-test & \multirow[t]{2}{*}{7} & 12 & 0.60 & 0.503 & \multirow[t]{2}{*}{0.015} \\
\hline Post-test & & 19 & 0.95 & 0.224 & \\
\hline Pre-test & \multirow[t]{2}{*}{8} & 9 & 0.45 & 0.510 & \multirow[t]{2}{*}{0.002} \\
\hline Post-test & & 19 & 0.95 & 0.224 & \\
\hline Pre-test & \multirow[t]{2}{*}{9} & 5 & 0.25 & 0.444 & \multirow[t]{2}{*}{0.000} \\
\hline Post-test & & 19 & 0.95 & 0.224 & \\
\hline Pre-test & \multirow[t]{2}{*}{10} & 3 & 0.15 & 0.366 & \multirow[t]{2}{*}{0.000} \\
\hline Post-test & & 16 & 0.80 & 0.410 & \\
\hline Pre-test & \multirow[t]{2}{*}{11} & 8 & 0.40 & 0.503 & \multirow[t]{2}{*}{0.000} \\
\hline Post-test & & 18 & 0.90 & 0.308 & \\
\hline Pre-test & \multirow[t]{2}{*}{12} & 8 & 0.40 & 0.503 & \multirow[t]{2}{*}{0.000} \\
\hline Post-test & & 20 & 1.00 & 0.000 & \\
\hline Pre-test & \multirow[t]{2}{*}{13} & 8 & 0.40 & 0.503 & \multirow[t]{2}{*}{0.000} \\
\hline Post-test & & 20 & 1.00 & 0.000 & \\
\hline Pre-test & \multirow[t]{2}{*}{14} & 13 & 0.65 & 0.489 & \multirow[t]{2}{*}{0.005} \\
\hline Post-test & & 20 & 1.00 & 0.000 & \\
\hline Pre-test & \multirow[t]{2}{*}{15} & 16 & 0.80 & 0.410 & \multirow[t]{2}{*}{0.042} \\
\hline Post-test & & 20 & 1.00 & 0.000 & \\
\hline Pre-test & \multirow[t]{2}{*}{16} & 14 & 0.70 & 0.470 & \multirow[t]{2}{*}{0.010} \\
\hline Post-test & & 20 & 1.00 & 0.000 & \\
\hline Pre-test & \multirow[t]{2}{*}{17} & 12 & 0.60 & 0.503 & \multirow[t]{2}{*}{0.002} \\
\hline Post-test & & 20 & 1.00 & 0.000 & \\
\hline
\end{tabular}

Table 4. Significant items (9A). 


\begin{tabular}{|c|c|c|c|c|c|}
\hline Item & Item & Total mark & Mean & Std. Deviation & Sig. (2-tailed) \\
\hline Pre-test & \multirow[t]{2}{*}{2} & 1 & 0.07 & 0.258 & \multirow[t]{2}{*}{0.000} \\
\hline Post-test & & 10 & 0.67 & 0.488 & \\
\hline Pre-test & \multirow[t]{2}{*}{5} & 4 & 0.27 & 0.458 & \multirow[t]{2}{*}{0.009} \\
\hline Post-test & & 10 & 0.67 & 0.488 & \\
\hline Pre-test & \multirow[t]{2}{*}{6} & 0 & 0.00 & 0.000 & \multirow[t]{2}{*}{0.000} \\
\hline Post-test & & 9 & 0.60 & 0.507 & \\
\hline Pre-test & \multirow[t]{2}{*}{8} & 0 & 0.00 & 0.000 & \multirow[t]{2}{*}{0.009} \\
\hline Post-test & & 6 & 0.40 & 0.507 & \\
\hline Pre-test & \multirow[t]{2}{*}{9} & 1 & 0.07 & 0.258 & \multirow[t]{2}{*}{0.000} \\
\hline Post-test & & 12 & 0.80 & 0.414 & \\
\hline Pre-test & \multirow[t]{2}{*}{10} & 0 & 0.00 & 0.000 & \multirow[t]{2}{*}{0.000} \\
\hline Post-test & & 13 & 0.87 & 0.352 & \\
\hline Pre-test & \multirow[t]{2}{*}{11} & 1 & 0.07 & 0.258 & \multirow[t]{2}{*}{0.000} \\
\hline Post-test & & 15 & 0.10 & 0.000 & \\
\hline Pre-test & \multirow[t]{2}{*}{12} & 5 & 0.33 & 0.488 & \multirow[t]{2}{*}{0.014} \\
\hline Post-test & & 12 & 0.80 & 0.414 & \\
\hline Pre-test & \multirow[t]{2}{*}{14} & 3 & 0.20 & 0.414 & \multirow[t]{2}{*}{0.004} \\
\hline Post-test & & 10 & 0.67 & 0.488 & \\
\hline Pre-test & \multirow[t]{2}{*}{15} & 11 & 0.73 & 0.458 & \multirow[t]{2}{*}{0.041} \\
\hline Post-test & & 15 & 1.00 & 0.000 & \\
\hline Pre-test & \multirow[t]{2}{*}{17} & 9 & 0.60 & 0.507 & \multirow[t]{2}{*}{0.009} \\
\hline Post-test & & 15 & 1.00 & 0.000 & \\
\hline
\end{tabular}

Table 5. Significant items (9J).

\section{Acknowledgements}

The Geography Learning Study reported here would not have been possible without the dedication of Maszalina $\mathrm{Hj}$ Zakaria, Hjh Noraini Hj Abd Rahman, Hjh Norhayti Md Salleh and Siti Rokiah $\mathrm{Hj}$ Husin who formed the teacher group. The EU - Asia Seminar on Teacher Education Policy sponsored by the European Network of Educational Research on Citizenship Education (ENERCE) was facilitated by Professor Javier Calvo de Mora, University of Granada, 14 -17 February, 2012.

\section{References}

Andrew, V. (2011). Enabling teachers to teach better: a practice based teacher professional development strategy to raise achievement in schools in Brunei Darussalam
(Doctoral Dissertation). University of Brunei Darussalam. [Back to text]

Dahlgren, L.O. \& Marton, F. (1978). Students' conceptions of subject matter: an aspect of learning and teaching in higher education. Studies in Higher Education, 3(1), 25-35.

[Abstract] [Back to text]

Davies, P. \& Brant, J. (2006). Business, economics and enterprise: teaching school subjects 11-19. London: Routledge .

[Abstract] [Back to text]

Davies, P. \& Dunnill, R. (2008). Learning Study as a model of collaborative practice in initial teacher education. Journal of Education for Teaching, 34(1), 3-16. [Full text] [Back to text]

Elliott, J. (2009). Lesson and Learning Study: a globalizing form of 
teacher research. Paper presented at the Annual Conference of the British Educational Research Association. University of Manchester. [Back to text]

Elliott, J. \& Yu, C. (2008). Learning studies as an educational change strategy in Hong Kong. Hong Kong: Hong Kong Institute of Education.

[Back to text]

Holmqvist, M., Gustavsson, L. \& Wernberg, A. (2008). Variation Theory: An Organizing Principle to Guide Design Research in Education In A. E. Kelly, R. A. Lesh \& J. Y. Baek (Eds), Handbook of design research methods in education: innovations in sciencie, technology, engineering, and mathematics learning and teaching (pp. 111-130). New York: Routledge. [Abstract] [Back to text]

Kelly, A. E., Lesh, R. A. \& Baek, J. Y. (2008). Handbook of design research methods in education. New York: Routledge. [Back to text]

Lewis, C., Perry, R. \& Friedkin, S. (2009). Lesson study as action research. In S. Noffke \& B. Somekh (Eds), The Sage Handbook of Educational Action Research (pp. 142-154). London: Sage.

[Back to text]

Lo, M.L., Pong, W.Y. \& Pakey, C.P.M. (2005). For each and everyone. Catering for individual differences through Learning Studies. Hong Kong: HKU Press. [Full text] [Back to text]
Lo, M.L. \& Marton, F. (2012). Towards a science of the art of teaching: using variation theory as a guiding principle of pedagogical design. International Journal of Lesson and Learning Studies, 1(1), 7-22. [Full text] [Back to text]

Marton, F. \& Booth, S. (1997). Learning and Awareness. Mahwah, NJ: Lawrence Erlbaum. [Full text] [Back to text]

Marton, F. \& Tsui, A. B. (2004). Classroom discourse and the space of learning. Mahwah, $\mathrm{NJ}$ : Lawrence Erlbaum. [Full text] [Back to text]

Marton, F. \& Pang, M. F. (2006). On some necessary conditions of learning. The Journal of the Learning Sciences, 15(2), 193220. [Abstract] [Back to text]

Runesson, U. \& Marton, F. (2002). The object of learning and the space of variation. In F. Marton \& P. Morris (Eds.), What Matters? Discovering critical conditions for classroom learning. Göteborg, Sweden: Acta Universitatis Gothoburgensis. [Back to text]

Ruthven, K., Laborde, C., Leach, J. \& Tiberghien, A. (2009). Design tools in didactical research: instrumenting the epistemological and cognitive aspects of the design of teaching sequences. Educational Researcher, 38(5), 329-342. [Full text] [Back to text]

Wood, K. (2000). The experience of learning to teach: changing student teachers' ways of understanding teaching. Journal of Curriculum Studies, 32(1), 
75-93. [Full text] [Back to text]

Yoshida, M. (1999). Lesson Study: A case study of a Japanese approach to improving instruction through schoolbased teacher development (Doctoral Dissertation). University of Chicago.

[Back to text]
Zakaria, M., Abd Rahman, N., Md Salleh, N., \& Husin, S. R. (2010). Changing dimensions: report of a Learning Study in Geography (Master of Education Report). Universiti Brunei Darussalam. [Back to text] 